\title{
Methylibium petroleiphilum gen. nov., sp. nov., a novel methyl tert-butyl ether-degrading methylotroph of the Betaproteobacteria
}

\author{
Correspondence \\ Cindy H. Nakatsu \\ cnakatsu@purdue.edu
}

\author{
Cindy H. Nakatsu, ${ }^{1}$ Krassimira Hristova, ${ }^{2}$ Satoshi Hanada, ${ }^{3}$ \\ Xian-Ying Meng, ${ }^{3}$ Jessica R. Hanson, ${ }^{2}$ Kate M. Scow ${ }^{2,4}$ \\ and Yoichi Kamagata ${ }^{3}$
}

\author{
${ }^{1}$ Department of Agronomy, Purdue University, West Lafayette, IN 47907-2054, USA \\ ${ }^{2,4}$ Department of Land, Air and Water Resources ${ }^{2}$ and Department of Microbiology ${ }^{4}$, University \\ of California, Davis, CA 95616, USA \\ ${ }^{3}$ Institute for Biological Resources and Functions, National Institute of Advanced Industrial \\ Science and Technology (AIST), Central 6, Higashi 1-1-1, Tsukuba, Ibaraki 305-8566, Japan
}

Organisms that can use one-carbon compounds as energy sources are called methylotrophs (Lidstrom, 2001). A subset of this group, the methanotrophs, can use methane as their sole carbon source. Methylotrophs have been extensively studied because of their potential use in biotechnology and bioremediation (Lidstrom \& Stirling, 1990; Hanson \& Hanson, 1996). The aerobic methylotrophs have representatives in the Proteobacteria, high $-\mathrm{G}+\mathrm{C}$ and low $-\mathrm{G}+\mathrm{C}$ Gram-positive bacteria that have been isolated from diverse environments. Within the Proteobacteria, the majority of the methylotrophs that have been isolated belong to either the Alphaproteobacteria or Gammaproteobacteria. Three genera, Methylobacillus (Urakami \& Komagata, 1986), Methylophilus

Published online ahead of print on 4 March 2005 as DOI 10.1099/ ijs.0.63524-0.

Abbreviations: MTBE, methyl tert-butyl ether; PHB, poly- $\beta$-hydroxybutyrate.

The GenBank/EMBL/DDBJ accession number for the 16S rRNA gene sequence of strain $\mathrm{PM} 1^{\top}$ is $\mathrm{AF} 176594$.
(Jenkins et al., 1987) and Methylovorus (Govorukhina \& Trotsenko, 1991), in the class Betaproteobacteria are considered to be restricted facultative methylotrophs because they can use methanol but not methane as a sole carbon source, and can use only a limited number of other carbon sources such as glucose and fructose. Phylogenetic analysis based on their 16S rRNA gene sequence resulted in all of them being grouped in the order Methylophilales (Bratina et al., 1992; Garrity \& Holt, 2001). Currently, none of the described methanotrophs belong to the class Betaproteobacteria. However, comparison of the $16 \mathrm{~S}$ rRNA gene sequence indicated that isolate $\mathrm{PM} 1^{\mathrm{T}}$ was most closely related to the class Betaproteobacteria in the SphaerotilusLeptothrix group (Bruns et al., 2001). In this study, morphological, physiological, biochemical and genetic information is used to propose a new genus and species, Methylibium petroleiphilum gen. nov., sp. nov.

Strain $\mathrm{PM} 1^{\mathrm{T}}$ was isolated from a mixed bacterial culture enriched with methyl tert-butyl ether (MTBE) using a bench-scale biofilter inoculated with material from a 
compost biofilter from the Los Angeles County Joint Water Pollution Control Plant (Carson, CA, USA) (Hanson et al., 1999). Isolates were obtained on minimal medium ( $\mathrm{Mu} \&$ Scow, 1994) with MTBE (25 mg HPLC grade, 99.9\% pure; Fisher Scientific) as the sole carbon source. MTBE utilization was confirmed by monitoring the disappearance of the substrate using gas chromatography (Shimadzu GC$14 \mathrm{~A}$, equipped with a photonionization detector). MTBE mineralization was determined by measuring ${ }^{14} \mathrm{CO}_{2}$ production using uniformly labelled $\left[{ }^{14} \mathrm{C}\right] \mathrm{MTBE}$ (NEN Life Science Products). Strain $\mathrm{PM}^{\mathrm{T}}$ and its relatives have been found to completely mineralize this compound and can do so at rates that have made it an appealing choice for use in the bioremediation of contaminated sites (Hristova et al., 2001). MTBE is a gasoline additive that is not readily degraded in all environments and therefore has become a widespread contaminant of groundwater in the USA (Squillace et al., 1996). The compound consists of four methyl groups surrounding a carbon monoxide and is produced from chemically reacting methanol and isobutylene. Two pathways for the degradation of this compound have been described to date. The initial step for both pathways is the conversion of MTBE to hydroxymethyl tert-butyl ether; then, in the pathway described for propane-oxidizing bacteria, tert-butyl alcohol and formaldehyde are formed (Steffan et al., 1997). In the degradation pathway used by Mycobacterium species, MTBE is converted to tert-butyl ether and then hydrolysed to tert-butyl alcohol and formate (François et al., 2002; Smith et al., 2003). Formaldehyde and formate both enter the $\mathrm{C}_{1}$ metabolic cycle, involved in the cycling of one-carbon compounds, where $\mathrm{CO}_{2}$ and $\mathrm{NADH}$ are generated (Ellis et al., 2001). Strain $\mathrm{PM1}^{\mathrm{T}}$ grows on tert-butyl alcohol, formaldehyde and formate (K. Hristova and K. M. Scow, unpublished results), suggesting that at least part of its MTBE biodegradation pathway is similar to that reported for cometabolizers.

Cell morphology and motility were examined under a phase-contrast microscope (Olympus AX80T) and a Zeiss EM 109 transmission electron microscope (TEM) operated at $80 \mathrm{kV}$. Cells were grown in minimal medium and a mixture of sodium glutamate, sodium succinate, sodium acetate, yeast extract and Casamino acids (each $0 \cdot 5 \mathrm{~g}^{-1}$ ), or minimal medium with MTBE as the sole carbon source. For TEM examination the cells were suspended in Millipore-filtered distilled water, and single drops of the cell suspension were placed on carbon- and Formvar-coated copper grids. Single drops of $1 \%(\mathrm{w} / \mathrm{v})$ aqueous uranyl acetate were added to the grid for 10-20 s. The cell ultrastructure was also examined using thin sections observed using a model H-7000 electron microscope operating at $75 \mathrm{kV}$ (Hitachi). The thin sections were prepared by rapidly freezing concentrated cells in liquid nitrogen, followed by fixation with an acetone/osmium tetroxide $(2 \%, w / v)$ solution by freeze-substitution. The fixed cells were then embedded in Spurr resin (Quetol 653). The thin sections were double-stained with uranyl acetate and lead citrate.
Media for the detection of starch, casein, DNA and gelatinase hydrolysis, and for nitrate reduction, were prepared according to the Difco Manual. Modified aesculin agar contained $0.01 \%(\mathrm{w} / \mathrm{v})$ aesculin, $0.05 \%(\mathrm{w} / \mathrm{v})$ iron(III) citrate, $5 \mathrm{~g}$ beef extract $\mathrm{l}^{-1}, 5 \mathrm{~g}$ peptone $\mathrm{l}^{-1}$ and $15 \%(\mathrm{w} / \mathrm{v})$ agar. Urea hydrolysis was determined by using commercially available urea agar (Remel). Cells for catalase and oxidase tests were grown on nutrient agar. API 20NE biochemical tests were conducted according to the manufacturer's instructions (bioMérieux). Quinones were analysed as described previously (Tamaoka et al., 1983), by using reversed-phase HPLC (Beckman System Gold with a Hewlett Packard Zorbox ODS column). Cellular fatty acid methyl esters were analysed by using a Hitachi M7200A GC/ 3DQMS system, equipped with a DB-5ms capillary column $(30 \mathrm{~m} \times 0.25 \mathrm{~mm})$ coated with $5 \%$ phenyl-methylpolysiloxane (J \& W Scientific) (Hanada et al., 1995). The G + C content was measured by HPLC, as described previously (Kamagata \& Mikami, 1991).

Growth of strain $\mathrm{PM}^{\mathrm{T}}$ in mineral salts medium (MSM) (Mu \& Scow, 1994) with MTBE as the sole carbon source or $0.5 \times$ strength liquid tryptic soy broth (Difco) was tested at various temperatures $\left(25,30\right.$ and $\left.37^{\circ} \mathrm{C}\right)$ and $\mathrm{pH}$ values $(5 \cdot 0-10 \cdot 0$ in $0 \cdot 5$ increments), and with various vitamins and trace metals (mixture and individual metals). Additional carbon sources such as pyruvate, acetate, citrate, L-asparagine, DL-alanine and glycine at $0.01 \%(\mathrm{w} / \mathrm{v})$, and butanol, ethanol and methanol at $0 \cdot 1 \%(\mathrm{v} / \mathrm{v})$, utilized by $\mathrm{PM1}^{\mathrm{T}}$ were also tested in MSM. Growth in the presence of a number of aromatic hydrocarbons, including benzoate, benzene, 2,3-dihydroxybenzoate, 2,4-dihydroxybenzoate, 2,5-dihydroxybenzoate, 2,6-dihydroxybenzoate, 3,4-dihydroxybenzoate, 3,5-dihydroxybenzoate, ethylbenzene, naphthalene, toluene and xylene was also investigated. Anaerobic growth was tested at $30^{\circ} \mathrm{C}$ using DSMZ334 liquid culture medium (DSMZ, 2001), with acetate as the carbon source and sparged with an $\mathrm{H}_{2} / \mathrm{CO}_{2}$ mixture $(80: 20$ ratio). All growth tests were performed in triplicate at $28^{\circ} \mathrm{C}$ for 24-77 h, and turbidity was monitored by spectrophotometry (Spectronic 20 D +; Milton Roy Analytical Div.) at $525 \mathrm{~nm}$.

DNA was extracted from cultures, after growth in MSM plus MTBE as the carbon source, using a Fast DNA extraction kit (Q-BIOgene), according to the manufacturer's instructions. The presence of genes encoding aromatic oxygenase that could potentially be involved in the degradation of some of the aromatic hydrocarbon growth substrates tested was determined using previously described PCR primers and conditions (Baldwin et al., 2003). Primers and conditions previously described by Holmes et al. (1995) and Miguez et al. (1997) were also used to determine the presence of genes encoding particulate methane monooxygenase (pMMO) and soluble methane monooxygenase (sMMO), respectively.

The 16S rRNA gene sequence of strain $\mathrm{PM1}^{\mathrm{T}}$ was determined previously (Bruns et al. 2001) (GenBank accession 
no. AF176594). Phylogenetic trees were constructed by calculating distances (Kimura and maximum-likelihood) and clustering [neighbour-joining method (Saitou \& Nei, 1987) with 1000 bootstrap, using DNAMAN version 4.1 software (Lynnon Biosoft)]. Reference sequences (GenBank; Benson et al., 2003) chosen were those of previously described methylotrophic members of the class Betaproteobacteria and the closest phylogenetic relatives of strain $\mathrm{PMI}^{\mathrm{T}}$ that represent strains from species with validly published names. Only nearly complete $16 \mathrm{~S}$ rRNA gene sequences (approximately $1500 \mathrm{bp}$ ) with a minimal number of ambiguous bases were chosen, and were optimally aligned prior to tree construction.

Under all growth conditions tested, the cells grew singly as $0.5 \times 1-2 \mu \mathrm{m}$ rods, without a sheath (Fig. 1), were motile by means of a single polar flagellum (Fig. 1b) and reproduced by normal cell division. Strain $\mathrm{PM1}^{\mathrm{T}}$ was Gram-negative, oxidase-positive and catalase-negative, and was capable of hydrolysing urea but not starch, gelatin, aesculin, casein or DNA. Nitrate was reduced to nitrite, but nitrite was not reduced. API 20NE test results were negative for $o$-nitrophenyl $\beta$-D-galactopyranoside, lysine decarboxylase, ornithine decarboxylase, citrate, indole, Voges-Proskauer test, glucose, rhamnose, sucrose, melibiose, arabinose and xylose. Centrally located intracellular granules were observed, which were considered to be poly- $\beta$-hydroxybutyrate (PHB) granules (Fig. 1c). This reserve material is commonly found in members of the Sphaerotilus-Leptothrix group (Spring, 2002). The characteristic cell morphology of members of the SphaerotilusLeptothrix group of sheathed cells growing filamentously with oxidized manganese or iron deposits was not observed (Table 1). Instead, the cell morphology was more similar to that of members of the genus Aquabacterium, which was also a member of this clade (Kalmbach et al., 1999), except that a surficial fibrillar matrix was not observed. Additionally, intracytoplasmic membrane structures of any type indicative of most methanotrophs were not observed (Bowman, 2000).
Within 2-3 days on nutrient agar, strain $\mathrm{PM}^{\mathrm{T}}$ formed cream-coloured, flat colonies with smooth margins, of 2-3 $\mathrm{mm}$ in diameter. Colonies were white in colour when the strain was grown on minimal media with MTBE as the sole carbon source. No pink or orange colony pigmentation was observed, which is often indicative of some methanotrophs (Bowman, 2000). Vitamins were not required for growth; subculture of strain $\mathrm{PM}^{\mathrm{T}}$ in medium without vitamins had no effect on growth. Trace metals required for the use of MTBE as a sole carbon source were $\mathrm{Co}, \mathrm{Cu}$, $\mathrm{Mn}, \mathrm{Zn}, \mathrm{Mo}, \mathrm{Ni}$ and Fe. Strain $\mathrm{PM}^{\mathrm{T}}$ could grow both aerobically and anaerobically. Other genera in the Leptothrix group whose members are also facultative aerobes are Rubrivivax, Ideonella and Aquabacterium (Spring, 2002). Facultatively anaerobic methylotroph representatives also occur (Lidstrom, 2001); therefore the occurrence of this phenotype is not unusual.

Strain $\mathrm{PM}^{\mathrm{T}}$ could utilize a number of organic acids and carbohydrates as sole carbon sources. Of the various substrates tested, $\mathrm{PM}^{\mathrm{T}}$ grew on the following compounds as sole carbon sources (in decreasing order of turbidity): ethanol, pyruvate, L-asparagine, acetate, butanol, DLalanine, methanol and MTBE. Growth was not observed on citrate or DL-glycine. The number of aromatic hydrocarbons that could be utilized was striking, many of which would co-occur with MTBE in gasoline-contaminated sites. Of those tested, growth was observed (in decreasing order of turbidity) in toluene, benzene, phenol, ethylbenzene, 3,4-dihydroxybenzoate, 2,5-dihydroxybenzoate, 3, 5-dihydroxybenzoate, 2,6-dihydroxybenzoate and 2,3dihydroxybenzoate. The optical densities of cultures were maintained in 2,4-dihydroxybenzoate, naphthalene and xylene; there was no substantial increase in turbidity. Typically, the range of substrates that can be used by methylotrophs is limited (Lidstrom, 2001). Other physiological traits of the strain when grown in MTBE have been reported previously (Hanson et al., 1999). Concentrations of MTBE as the sole carbon and energy source of as high as $500 \mu \mathrm{g} \mathrm{ml}^{-1}$ could be degraded, and support growth. At
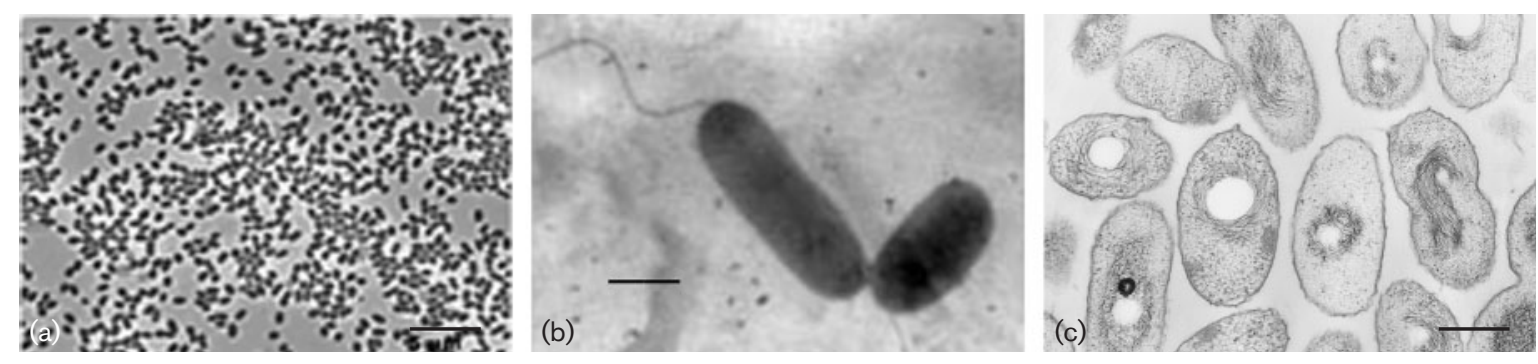

Fig. 1. Photomicrographs of Methylibium petroleiphilum strain $P M 1^{\top}$. (a) Phase-contrast micrograph of unstained cells of strain $\mathrm{PM} 1^{\top}$ after 2 days of growth on minimal medium plus a mixed carbon source. (b) Electron micrograph of negatively stained cells of strain $\mathrm{PM}^{\top}{ }^{\top}$ after growth on minimal medium plus MTBE showing a single polar flagellum. (c). Electron micrograph of thin sections of negatively stained cells of strain $\mathrm{PM} 1^{\top}$ after 2 days of growth on minimal medium plus MTBE. Bars, $5 \mu \mathrm{m}(\mathrm{a})$ and $0.5 \mu \mathrm{m}(\mathrm{b}$ and $\mathrm{c})$. 
Table 1. Comparison of characteristics of the genera phylogenetically close to strain $\mathrm{PM} 1^{\top}$

Taxa: 1, [Alcaligenes] latus; 2, [Pseudomonas] saccharophila; 3, Roseateles; 4, Rubrivivax; 5, Ideonella; 6, Leptothrix; 7, Sphaerotilus; 8, Aquabacterium; 9, strain $\mathrm{PM1}^{\mathrm{T}}$. Adapted from Spring (2002). +, Present in all species; -, absent from all species; NR, not reported.

\begin{tabular}{|c|c|c|c|c|c|c|c|c|c|}
\hline Characteristic & 1 & 2 & 3 & 4 & 5 & 6 & 7 & 8 & 9 \\
\hline Flagellation & Peritrichous & $\begin{array}{l}\text { One } \\
\text { polar }\end{array}$ & $\begin{array}{l}\text { Several } \\
\text { polar }\end{array}$ & $\begin{array}{l}\text { One } \\
\text { polar }\end{array}$ & $\begin{array}{l}\text { Several, polar } \\
\text { or subpolar }\end{array}$ & $\begin{array}{l}\text { One polar; } \\
\text { subpolar tuft }\end{array}$ & Subpolar tuft & $\begin{array}{l}\text { One } \\
\text { polar }\end{array}$ & $\begin{array}{l}\text { One } \\
\text { polar }\end{array}$ \\
\hline Formation of sheaths & - & - & - & - & - & + & + & - & - \\
\hline Carotenoid pigments & - & - & + & + & - & - & - & - & - \\
\hline Photoautotrophic growth & - & - & - & + & - & - & - & - & - \\
\hline Oxidation of $\mathrm{Mn}^{2+}$ & - & NR & NR & NR & NR & + & - & - & NR \\
\hline Methanol as sole carbon source & NR & NR & NR & NR & NR & NR & NR & - & + \\
\hline $\mathrm{G}+\mathrm{C}$ content $(\mathrm{mol} \%)$ & NR & 69 & 66 & $70-72$ & 68 & $68-71$ & 69 & $65-66$ & 69 \\
\hline Isolation source & Soil & Mud & $\begin{array}{l}\text { River } \\
\text { water }\end{array}$ & Mud & $\begin{array}{l}\text { Activated } \\
\text { sludge }\end{array}$ & $\begin{array}{c}\text { Freshwater, } \\
\text { sediment }\end{array}$ & $\begin{array}{c}\text { Freshwater, } \\
\text { activated sludge }\end{array}$ & $\begin{array}{l}\text { Drinking } \\
\text { water }\end{array}$ & Biofilter \\
\hline
\end{tabular}

the time of the study by Hanson et al. (1999), protein analysis indicated that a substantial increase in biomass did not occur when MTBE was used as a carbon source, approximately $0 \cdot 18 \mathrm{mg}$ cells $(\mathrm{mg} \mathrm{MTBE})^{-1}$. Higher yields have been obtained since this initial value was published, with optimization of the culture conditions for growth of strain $\mathrm{PM}^{\mathrm{T}}$ (K. Hristova and K. M. Scow, unpublished results).

To gain insight into the novelty of the genes potentially involved in the utilization of some of the growth substrates tested, PCR was performed using a variety of primers that had been used previously to detect genes encoding oxygenase (Baldwin et al., 2003). PCR products were obtained with primers specific for genes encoding ring-hydroxylating toluene monooxygenase and phenol hydroxylase. The presence of these genes suggested that degradation of at least some of the aromatic hydrocarbons involved catabolic pathways that have been previously described in other bacteria. No products were observed with the other oxygenase gene primers used. Also, no PCR amplicons were produced using primers for the sMMO or pMMO genes that are typically found in methanotrophs. The 16S rRNA gene sequence of isolate L013.11 was found to closely match that of strain $\mathrm{PM}^{\mathrm{T}}$ (Fig. 2). This isolate has not been cultivated, but was found in peat soil after methane enrichment with ${ }^{13} \mathrm{CH}_{4}$ (Morris et al., 2002). The authors of that study speculated that this strain was a novel representative of methanotrophs within the class Betaproteobacteria. The close phylogenetic relationship of isolate L013.11 to strain $\mathrm{PM}^{\mathrm{T}}$ suggests that it is at least methylotrophic, but further research is needed to clarify the role played by this strain in methane-enriched communities.

Phylogenetic analysis using the 16S rRNA gene indicated that strain $P M 1^{\mathrm{T}}$ fell into the Sphaerotilus-Leptothrix subcluster within the class Betaproteobacteria (Spring, 2002). The sequence formed a separate branch from those of the described genera in this group, Leptothrix, Aquabacterium, Roseateles, Sphaerotilus, Ideonella and Rubrivivax (Fig. 2).
Using 16S rRNA gene sequence identity, the most closely related bacterium with a validly published name was Aquabacterium commune DSM $11901^{\mathrm{T}}$ (96\%), followed closely by others in the same clade, Aquabacterium citratiphilum DSM $11900^{\mathrm{T}}$ (95\%), Aquabacterium parvum DSM $11968^{\mathrm{T}}$ (95\%), Ideonella dechloratans ATCC $51718^{\mathrm{T}}$ (95\%), Leptothrix discophora ATCC 51168 (95\%), Leptothrix cholodnii strain CCM 1827 (95\%), Leptothrix mobilis DSM $10617^{\mathrm{T}}$ (94\%), Rubrivivax gelatinosus ATCC $17011^{\mathrm{T}}(95 \%)$, Roseateles depolymerans DSM $11813^{\mathrm{T}}(94 \%)$ and Sphaerotilus sp. IF5 (93\%). Isolates from this group have been obtained from a wide variety of environments and display diverse physiologies. However, there are no reports of any of these bacteria being able to use methanol as a sole carbon source. The sequence identity to four methylotrophic species that belong to the class Betaproteobacteria was much lower: Methylobacillus pratensis NCIMB $13994^{\mathrm{T}}$ had $85 \%$ identity; 'Methylophilus freyburgensis' strain I 42T, $85 \%$; Methylophilus leisingeri DSM 6813 ${ }^{\mathrm{T}}, 83 \%$; and Methylophilus methylotrophus ATCC $53528^{\mathrm{T}}$, $80 \%$. The $16 \mathrm{~S}$ rRNA gene sequence analysis indicates that strain $\mathrm{PM} 1^{\mathrm{T}}$ represents a new genus and species.

The almost full-length 16S rRNA gene sequences with the highest identity to that of strain $\mathrm{PM}^{\mathrm{T}}$ were from clones made from PCR amplicons of DNA obtained directly from polluted locations that represent uncultivated bacteria. As mentioned above, one of the best-matching sequences was that of strain L013.11 (97\% identity) (Fig. 2), which was amplified from peat soil after methane enrichment with ${ }^{13} \mathrm{CH}_{4}$ (Morris et al., 2002). This suggests that the methylotrophic trait of strain $\mathrm{PM}^{\mathrm{T}}$ is not unique. Examples of other closely matching sequences were those of strain HTCC304 isolated from trichloroethylene- and cis-dichloroethylene-contaminated groundwater (GenBank accession no. AY429720; $99 \%$ identity), clone Spb03 isolated from biofilms in the extremely polluted Spittelwasser River (AJ422152; $98 \%$ identity) (Brummer et al., 2003) and clone S1B10 isolated from activated sludge enriched with nonylphenol (AY382153; $96 \%$ identity). 


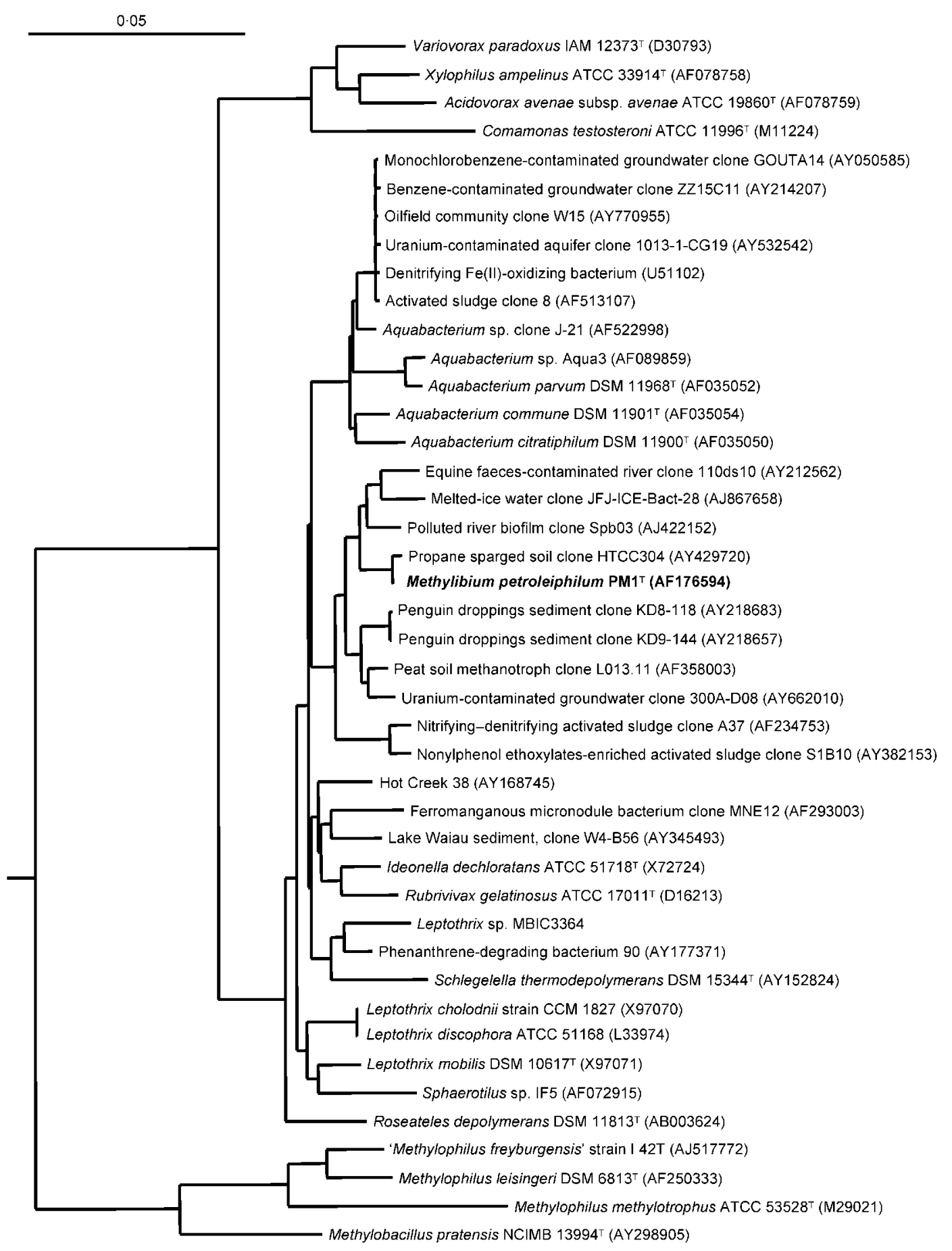

Fig. 2. Phylogenetic position of strain $P M 1^{\top}$ among neighbouring species selected from the class Betaproteobacteria. Bar, 0.05 substitution per nucleotide position in 16S rRNA gene sequences. GenBank accession numbers and culture collection numbers (where available) used in the tree construction are included on the figure.

Other environments from which related clones have been obtained are polychlorinated biphenyl-polluted soil (Nogales et al., 1999), groundwater contaminated with high levels of nitric acid-bearing uranium waste (clone 300A-D08; AY662010), a stream contaminated with equine faecal material (Simpson et al., 2004), benzenecontaminated groundwater (clone ZZ15C11; AY214207), penguin droppings (clone KD9-144; AY218657) and melted-ice water (clone JFJ-ICE-Bact-28; AJ867658). A better understanding of the physiology of this genus 
will probably result in the cultivation of more representatives of this group from a wide range of habitats.

Direct analysis of $16 \mathrm{~S}$ rRNA genes from MTBEcontaminated sites where MTBE-biodegradation potential has been demonstrated indicated that bacteria with $\mathrm{PM} 1^{\mathrm{T}}$-like sequences are common in these locations (Kane et al., 2001; Hristova et al., 2003; Smith et al., 2005). Sequences deposited in GenBank (AF409035, AF409034) from another MTBE study also indicate the possible presence of strains related to $\mathrm{PMl}^{\mathrm{T}}$. Using quantitative realtime PCR, changes in the density of $\mathrm{PM1}^{\mathrm{T}}$-like sequences in the native community of contaminated groundwater and sediment have been shown to correspond to MTBE removal (Hristova et al., 2003). These studies suggest that this bacterium is widespread and is a major component of microbial communities in MTBE-contaminated sediment and groundwater.

\section{Description of Methylibium gen. nov.}

Methylibium (Me.thy.li.bi'um. N.L. n. methyl the methyl radical, the methyl group; Gr. n. bios life; N.L. neut. n. Methylibium referring to methylotroph).

Cells are motile, Gram-negative straight rods. Oxidasepositive. Negative for gelatinase and catalase. Hydrolyse urea and reduce nitrate to nitrite. Cells possess PHB granules as a storage material and reproduce by binary fission. Growth occurs heterotrophically under aerobic conditions. Facultative methylotrophs able to use methanol as a sole carbon source in addition to a variety of other more complex carbon sources. The major quinone is Q-8. The major fatty acids are $\mathrm{C} 16: 1 \omega 7 c$ and $\mathrm{C} 16: 0$, and in lesser amounts $\mathrm{C} 10: 0$ 3-OH, C12:0, C12:0 2-OH, C12:0 3-OH, C14:0, C17:0 $\omega$ cyclo7-8c, C18: $1 \omega 7 c$ and C18:0. On the basis of the results of $16 \mathrm{~S}$ rRNA gene sequence comparison, the bacteria belong to the class Betaproteobacteria. The DNA $\mathrm{G}+\mathrm{C}$ content of the type species is $69 \mathrm{~mol} \%$. The type species is Methylibium petroleiphilum.

\section{Description of Methylibium petroleiphilum sp. nov.}

Methylibium petroleiphilum (pe.tro.lei.phi'lum. Gr. n. petra stone, rock; L. n. oleum oil; Gr. adj. philos loving; N.L. neut. adj. petroleiphilum petrol loving).

Exhibits the following properties in addition to those given in the genus description. Colonies are cream in colour under conditions suitable for MTBE degradation. Grows well heterotrophically in media containing ethanol, methanol, toluene, benzene, ethylbenzene and dihydroxybenzoates as the sole carbon source. Vitamins are not required for growth. Optimum $\mathrm{pH}$ and temperature for growth are 6.5 and $30^{\circ} \mathrm{C}$, respectively. Does not grow at $37^{\circ} \mathrm{C}$. The genome size is $4.6 \mathrm{Mb}$ (http://genome.jgi-psf.org/finished_ microbes/metpe/metpe.home.html). Inhabits subsurface environments highly contaminated with MTBE.
The type strain is $\mathrm{PM1}^{\mathrm{T}}$ (=ATCC BAA- $1232^{\mathrm{T}}=\mathrm{LMG}$ $22953^{\mathrm{T}}$ ), which was isolated from a mixed bacterial culture enriched using a bench-scale biofilter inoculated with some solid support material from a compost biofilter located at the Los Angeles County Joint Water Pollution Control Plant (Carson, CA, USA).

\section{Acknowledgements}

We thank colleagues at the National Institute of Advanced Industrial Science and Technology (AIST) for their assistance in this project. In particular, we thank Akiko Sunaga and Mizuho Muramatsu for quinone and DNA base composition determination. Financial support was provided by the NSF Microbial Observatories (NSF-MO MCB-0137210), NIEHS Molecular Structure/Function of Organisms Degrading Contaminants (1R21ES012812-01), NIEHS Superfund Basic Research Program (2P42 ESO 4699), American Petroleum Institute (API) and the Water Resources Center.

\section{References}

Baldwin, B. R., Nakatsu, C. H. \& Nies, L. (2003). Detection and enumeration of aromatic oxygenase genes by multiplex and real-time PCR. Appl Environ Microbiol 69, 3350-3358.

Benson, D. A., Karsch-Mizrachi, I., Lipman, D. J., Ostell, J. \& Wheeler, D. L. (2003). GenBank. Nucleic Acids Res 31, 23-27.

Bowman, J. P. (2000). The methanotrophs - the families Methylococcaceae and Methylocystaceae. In The Prokaryotes: an Evolving Electronic Resource for the Microbiological Community, 3rd edn, release 3.1, 20 January 2000. Edited by M. Dworkin, K. H. Schleifer \& E. Stackebrandt. New York: Springer-Verlag. http://link.springerny.com/link/service/books/10125/

Bratina, B., Brusseau, G. A. \& Hanson, R. S. (1992). Use of $16 \mathrm{~S}$ rRNA analysis to investigate phylogeny of methylotrophic bacteria. Int J Syst Bacteriol 42, 645-648.

Brummer, I. H. M., Felske, A. \& Wagner-Dobler, I. (2003). Diversity and seasonal variability of $\beta$-Proteobacteria in biofilms of polluted rivers: analysis by temperature gradient gel electrophoresis and cloning. Appl Environ Microbiol 69, 4463-4473.

Bruns, M. A., Hanson, J. R., Mefford, J. \& Scow, K. M. (2001). Isolate PM1 populations are dominant and novel methyl tert-butyl etherdegrading bacteria in compost biofilter enrichments. Environ Microbiol 3, 220-225.

DSMZ (2001). Catalogue of Strains. Braunschweig: German Collection of Microorganisms and Cell Cultures.

Ellis, L. B., Hershberger, C. D., Bryan, E. M. \& Wackett, L. P. (2001). The University of Minnesota Biocatalysis/Biodegradation Database: emphasizing enzymes. Nucleic Acids Res 29, 340-343.

François, A., Mathis, H., Godefroy, D., Piveteau, P., Fayolle, F. \& Monot, F. (2002). Biodegradation of methyl tert-butyl ether and other fuel oxygenates by a new strain, Mycobacterium austroafricanum IFP 2012. Appl Environ Microbiol 68, 2754-2762.

Garrity, G. M. \& Holt, J. G. (2001). Taxonomic outline of the Archaea and Bacteria. In Bergey's Manual of Systematic Bacteriology, 2nd edn, vol. 1, pp. 155-166. Edited by D. R. Boone, R. W. Castenholz \& G. M. Garrity. New York: Springer.

Govorukhina, N. I. \& Trotsenko, Y. A. (1991). Methylovorus, a new genus of restricted facultatively methylotrophic bacteria. Int J Syst Bacteriol 41, 158-162.

Hanada, S., Hiraishi, A., Shimada, K. \& Matsuura, K. (1995). Chloroflexus aggregans sp. nov., a filamentous phototrophic bacterium 
which forms dense cell aggregates by active gliding movement. Int J Syst Bacteriol 45, 676-681.

Hanson, R. S. \& Hanson, T. E. (1996). Methanotrophic bacteria. Microbiol Rev 60, 439-471.

Hanson, J. R., Ackerman, C. E. \& Scow, K. M. (1999). Biodegradation of methyl tert-butyl ether by a bacterial pure culture. Appl Environ Microbiol 65, 4788-4792.

Holmes, A. J., Costello, A., Lidstrom, M. E. \& Murrell, J. C. (1995). Evidence that particulate methane monooxygenase and ammonia monooxygenase may be evolutionarily related. FEMS Microbiol Lett 132, 203-208.

Hristova, K. R., Lutenegger, C. M. \& Scow, K. M. (2001). Detection and quantification of methyl tert-butyl ether-degrading strain PM1 by real-time TaqMan PCR. Appl Environ Microbiol 67, 5154-5160.

Hristova, K., Gebreyesus, B., Mackay, D. \& Scow, K. A. (2003). Naturally occurring bacteria similar to the methyl tert-butyl ether (MTBE)-degrading strain PM1 are present in MTBE-contaminated groundwater. Appl Environ Microbiol 69, 2616-2623.

Jenkins, O., Byrom, D. \& Jones, D. (1987). Methylophilus: a new genus of methanol-utilizing bacteria. Int J Syst Bacteriol 37, 446-448.

Kalmbach, S., Manz, W., Wecke, J. \& Szewzyk, U. (1999). Aquabacterium gen. nov., with description of Aquabacterium citratiphilum sp. nov., Aquabacterium parvum sp. nov. and Aquabacterium commune sp. nov., three in situ dominant bacterial species from the Berlin drinking water system. Int J Syst Bacteriol 49, 769-777.

Kamagata, Y. \& Mikami, E. (1991). Isolation and characterization of a novel thermophilic Methanosaeta strain. Int J Syst Bacteriol 41, 191-196.

Kane, S. R., Beller, H. R., Legler, T. C., Koester, C. J., Pinkart, H. C., Halden, R. U. \& Happel, A. M. (2001). Aerobic biodegradation of methyl tert-butyl ether by aquifer bacteria from leaking underground storage tank sites. Appl Environ Microbiol 67, 5824-5829.

Lidstrom, M. E. (2001). Aerobic methylotrophic prokaryotes. In The Prokaryotes: an Evolving Electronic Resource for the Microbiological Community, 3rd edn, release 3.7, 11 February 2001. Edited by M. Dworkin, K. H. Schleifer \& E. Stackebrandt. New York: SpringerVerlag. http://link.springer-ny.com/link/service/books/10125/

Lidstrom, M. E. \& Stirling, D. I. (1990). Methylotrophs: genetics and commercial applications. Annu Rev Microbiol 44, 27-58.

Miguez, C. B., Bourque, D., Sealy, J. A., Greer, C. W. \& Groleau, D. (1997). Detection and isolation of methanotrophic bacteria possessing soluble methane monooxygenase (sMMO) genes using the polymerase chain reaction (PCR). Microb Ecol 33, 21-31.

Morris, S. A., Radajewski, S., Willison, T. W. \& Murrell, J. C. (2002). Identification of the functionally active methanotroph population in a peat soil microcosm by stable-isotope probing. Appl Environ Microbiol 68, 1446-1453.

Mu, D. Y. \& Scow, K. M. (1994). Effect of trichloroethylene (TCE) and toluene concentrations on TCE and toluene biodegradation and the population density of TCE and toluene degraders in soil. Appl Environ Microbiol 60, 2661-2665.

Nogales, B., Moore, E. R. B., Abraham, W. R. \& Timmis, K. N. (1999). Identification of the metabolically active members of a bacterial community in a polychlorinated biphenyl-polluted moorland soil. Environ Microbiol 1, 199-212.

Saitou, N. \& Nei, M. (1987). The neighbor-joining method: a new method for reconstructing phylogenetic trees. Mol Biol Evol 4, 406-425.

Simpson, J. M., Santo Domingo, J. W. \& Reasoner, D. J. (2004). Assessment of equine fecal contamination: the search for alternative bacterial source-tracking targets. FEMS Microbiol Ecol 47, 65-75.

Smith, C. A., O'Reilly, K. T. \& Hyman, M. R. (2003). Cometabolism of methyl tertiary butyl ether and gaseous $n$-alkanes by Pseudomonas mendocina KR-1 grown on $\mathrm{C}_{5}$ to $\mathrm{C}_{8} n$-alkanes. Appl Environ Microbiol 69, 7385-7394.

Smith, A. E., Hristova, K., Wood, I., Mackay, D. M., Lory, E., Lorenzana, D. \& Scow, K. M. (2005). Comparison of biostimulation versus bioaugmentation with bacterial strain PM1 for treatment of groundwater contaminated with methyl tertiary butyl ether (MTBE). Environ Health Perspect 113, 317-322.

Spring, S. (2002). The genera Leptothrix and Sphaerotilus. In The Prokaryotes: an Evolving Electronic Resource for the Microbiological Community, 3rd edn, release 3.9, 1 April 2002. Edited by M. Dworkin, K. H. Schleifer \& E. Stackebrandt. New York: Springer-Verlag. http:// link.springer-ny.com/link/service/books/10125/

Squillace, P. J., Zogorski, J. S., Wilber, W. G. \& Price, C. V. (1996). Preliminary assessment of the occurrence and possible sources of MTBE in groundwater in the United States, 1993-94. Environ Sci Technol 30, 1721-1730.

Steffan, R. J., McClay, K., Vainberg, S., Condee, C. W. \& Zhang, D. (1997). Biodegradation of the gasoline oxygenates methyl tert-butyl ether, ethyl tert-butyl ether, and tert-amyl methyl ether by propaneoxidizing bacteria. Appl Environ Microbiol 63, 4216-4222.

Tamaoka, J., Katayama-Fujimura, Y. \& Kuraishi, H. (1983). Analysis of bacterial menaquinone mixtures by high performance liquid chromatography. J Appl Bacteriol 54, 31-36.

Urakami, T. \& Komagata, K. (1986). Emendation of Methylobacillus Yordy and Weaver 1977, a genus for methanol-utilizing bacteria. Int J Syst Bacteriol 36, 502-511. 